\title{
EVALUASI KUALITAS LAYANAN PERPUSTAKAAN FEB UNDIP BERDASARKAN HARAPAN DAN PERSEPSI PEMUSTAKA DENGAN METODE LibQUAL ${ }^{+T M}$
}

\author{
Oleh: Endang Fatmawati *)
}

\begin{abstract}
Library quality services evaluation is an important activity for academic libraries. This research is to evaluate service quality library at Economica and Business Faculty of Diponegoro University base on desired and perceived of users with LibQUAL $L^{+T M}$ methods. The aims to measurement library service quality from desired and perceived users, and to know service library dimensions don't fullfill desired and perceived users. Quality is defined as "capability" - how good is the library? LibQUAL $L^{+T M}$ is effective total survey market to context research in library to evaluation library quality service. Assessment based on perceived, minimum expectations, and desired. LibQUAL $L^{+T M}$ method gives users a chance to tell library where library services need improvement so it can respond to and better manage their expectations. Dimensions in LibQUAL ${ }^{+T M}$ consist of: Service Affect (SA), Library as Place (LP), Personal Control (PC), and Information Access (IA). Population is taken from Diploma III Program; Regular I, and Reguler II students, year 2009/2010 with proporsional stratified random sampling and the total sample is 81 respondents. This research used quantitative method with survey and evaluation research. Users were asked to complete a questionnaire. Analyze its to know average perceived, minimum, and desired. The distance of the perceived score from the minimum score $(P-M)$ creates a adequacy gap, and from the desired score $(P-I)$ creates a superiority gap. The result shows that library service quality is fullfill minimum expectation of users. This means users had "enough satisfaction" with service perceived.
\end{abstract}

Keywords: Evaluation, LibQUAL ${ }^{+T M}$, Library Quality Service, Adequacy Gap, Superiority Gap, Mean Difference T-Test.

*) Alumni mahasiswa MIP UGM dan Pustakawan UNDIP yang ditugaskan sebagai Kepala Perpustakaan FEB UNDIP \& Dosen LB UNDIP Pada Jurusan (MP-FEB, APSFISIP, PerPin-FIB, Kearsipan-FIB, maupun Ilmu Perpustakaan-FIB).

\section{A. Pendahuluan}

Bagi suatu perguruan tinggi, perpustakaan merupakan sarana penunjang yang sangat penting pada setiap program pendidikan dan pengajaran, penelitian, maupun pengabdian masyarakat. Untuk mencapai sasarannya, maka pustakawan berperan sangat penting dalam meningkatkan kualitas layanan perpustakaan. Era globalisasi maupun kemajuan TIK telah berpengaruh pada meningkatnya kompleksitas tuntutan civitas akademik terhadap layanan perpustakaan. Kualitas dipandang sebagai salah satu alat untuk mencapai keunggulan kompetitif (competitive advantage). Kondisi global saat ini, memaksa Perpustakaan FEB UNDIP menjadi perpustakaan riset (research library) untuk menghadapi persaingan tingkat dunia dalam mendukung UNDIP menuju WCU. Evaluasi layanan perpustakaan berdasarkan perspektif pemustaka merupakan hal yang penting untuk dilakukan mengingat bahwa yang dapat menilai suatu layanan adalah yang menerimanya. Salah satu metode terbaru untuk mengevaluasi kualitas layanan perpustakaan dan masih belum banyak diaplikasikan oleh perpustakaan di Indonesia adalah metode LibQUAL $^{+ \text {TM }}$.

Perumusan masalahnya: 1). Bagaimana kualitas layanan perpustakaan di Perpustakaan FEB UNDIP berdasarkan harapan dan persepsi pemustaka dengan menggunakan metode LibQUAL $+{ }^{\mathrm{TM}}$ ? dan 2). Dimensi layanan perpustakaan apa saja yang belum memenuhi harapan dan persepsi pemustaka di Perpustakaan FEB UNDIP dengan menggunakan metode LibQUAL $+{ }^{\mathrm{TM}}$ ?

\section{B. Tinjauan Pustaka dan Landasan Teori}

1. Tinjauan Pustaka

Ladhari \& Morales (2008: 356) menyatakan bahwa "positive word-of-mouth" antar 
pemustaka merupakan faktor kritik kesuksesan yang memegang peranan sangat penting dalam konteks proses layanan perpustakaan. Kualitas dalam perspektif penulis adalah lebih pada kemampuan (capability), yaitu sebaik apakah perpustakaan (how good is the library?) dalam melayani pemustakanya.

Fatmawati (2011: 188) menegaskan urgensi courtesy bagi pustakawan dalam melayani pemustaka. Courtesy pustakawan dapat diartikan sebagai kesopan-santunan, kesopanan; rasa hormat; kebaikan; maupun implementasi pelayanan yang baik yang dilakukan oleh pustakawan kepada pemustaka. Guna mencapai kualitas layanan perpustakaan yang standar, maka pustakawan seyogianya mulai belajar melayani pemustaka dengan prinsip "layanan berbasis pemustaka (people based service)" dan "layanan unggul (service excellence)", yang salah satu tema kuncinya adalah penerapan courtesy pustakawan.

Evaluasi tidak terlepas dengan yang namanya penilaian (assessment). Ping (2008: 104) menjelaskan bahwa dalam beberapa tahun, terjadi perbedaan pengukuran dalam menilai (to assess) kinerja perpustakaan, kepuasan pemustaka, dan begitu juga instrumen untuk mengukur persepsi kualitas layanan perpustakaan. Misalnya: bagaimana mengukur besarnya koleksi (Hernon and McClure, 1990); mengukur program Public Relations (PR) perpustakaan (Wolfe, 2004); mengukur pada layanan teknis seperti katalog dan penyiangan (Lancaster, 1993); mengukur kinerja layanan referensi (Aluri, 1993); maupun mengukur proses perpustakaan dengan menggunakan kriteria dari MBNQA dan standar ISO 9000. Wolfe (2004: 68) menjelaskan evaluasi adalah sebuah kesempatan bagi kita untuk melihat hal yang penting yang telah dicapai dan bahkan menjadikan kita dapat mencapai sesuatu hal yang lebih baik di waktu yang akan datang.

Evaluasi kualitas layanan perpustakaan dalam perspektif penulis yaitu penilaian terhadap aktivitas dan kebijakan yang sudah dilakukan oleh pihak perpustakaan untuk mengetahui hasil yang dicapai dari layanan yang sudah diberikan kepada pemustaka.

\section{Landasan Teori}

Asal usul/kelahiran LibQUAL ${ }^{+\mathrm{TM}}$ pada tahun 1999. Pelopornya adalah Fred Heath (Dean of Libraries; pemilik Sterling Evans Chair), dan Colleen Cook (Executive Associate Dean; Wright Profesor Ilmu Perpustakaan) yang keduanya dari Texas A\&M University (TAMU). Metode LibQUAL ${ }^{+T M}$ merupakan adaptasi instrumen yang terdapat dalam SERVQUAL ke dalam lingkungan perpustakaan. Awalnya model SERVQUAL dikembangkan oleh Parasuraman, Zeithaml, dan Berry $(1985,1988,1990,1991,1993$, 1994) dalam serangkaian penelitian terhadap enam sektor jasa. Sejauh pengamatan penulis, bahwa sampai saat ini belum banyak peneliti yang menggunakan metode LibQUAL ${ }^{\mathrm{TM}}$ untuk mengukur kualitas layanan di perpustakaan.

Penelitian terdahulu, metode pengukuran kualitas pelayanan perpustakaan dengan menggunakan LibQUAL ${ }^{\mathrm{TM}}$ telah diuji dalam beberapa penelitian, misalnya oleh Kemp (2001); Cook dan Heath (2001); Hitchingham, et.al. (2002); serta Boykin (2002). Prinsip LibQUAL $+{ }^{\mathrm{TM}}$ adalah hanya pemustaka yang berhak untuk menilai kualitas layanan, sementara seluruh penilaian lainnya sebenarnya tidak relevan.

Inti program LibQUAL ${ }^{+T M}$ ini adalah survei berbasis pemustaka untuk membantu perpustakaan dalam penilaian dan peningkatan layanan perpustakaan, merubah budaya organisasi, dan pemasaran perpustakaan. Metode LibQUAL ${ }^{+\mathrm{TM}}$ dapat memberikan kesempatan pemustaka untuk memberitahu dimana layanan perpustakaan yang perlu perbaikan, sehingga perpustakaan dapat menanggapi dan mengelola harapan pemustaka.

Dalam Powell \& Connaway (2004: 56) dijelaskan bahwa untuk menilai layanan yang telah diterima pemustaka di perpustakaan perguruan tinggi, maka ARL telah meneliti dan mengembangkan proyek yang disebut dengan LibQUAL ${ }^{+\mathrm{TM}}$. Sehingga Powell \& Connaway mendukung bahwa untuk mengetahui kualitas layanan perpustakaan dari perspektif pemustaka adalah dengan metode LibQUAL ${ }^{+T M}$. 
LibQUAL ${ }^{+T M}$ dapat digunakan untuk memecahkan masalah, melihat mana yang sudah benar atau yang salah dari perpustakaan, dengan tujuan utama untuk memperbaiki layanan kepada pemustaka. Hal ini seperti diungkapkan oleh Budd (2005: 146) bahwa salah satu model terbaru untuk menilai kualitas layanan dan beberapa elemen pada perpustakaan adalah dengan $L i b Q U A L^{+T M}$.

Metode LibQUAL $+^{\mathrm{TM}}$ digunakan untuk mengukur kualitas layanan perpustakaan berdasarkan persepsi dan harapan pemustaka. Persepsi (perceived) merupakan tingkat layanan yang kenyataannya diterima/dialami pemustaka. Sementara harapan dalam konsep LibQUAL $+{ }^{\mathrm{TM}}$ dibagi menjadi harapan minimum (minimum) dan harapan ideal (desired).

Harapan minimum (minimum expectation), yaitu serendah-rendahnya tingkat layanan minimum yang dapat diterima (acceptable) atau yang masih dapat ditolerir. Sementara harapan ideal (desired) merupakan tingkat layanan perpustakaan yang secara pribadi sebenarnya diinginkan atau diidealkan. Oleh karena itu, harapan ideal pemustaka tentu nilainya akan lebih besar daripada harapan minimum pemustaka.

LibQUAL $^{+\mathrm{TM}}$ tersebut memfokuskan persepsi pemustaka terhadap layanan prima (service excellent) yang dihubungkan dengan kepentingan relatif, level layanan sekarang, dan level minimal layanan yang dapat diterima. LibQUAL ${ }^{+\mathrm{TM}}$ merupakan "suite" layanan perpustakaan yang digunakan untuk mengumpulkan, memahami, dan bertindak atas pendapat pemustaka mengenai kualitas layanan.

Menurut Woodward (2009: 174), metode LibQUAL ${ }^{+T M}$ dilakukan dengan tujuan agar pustakawan dapat mengetahui kebutuhan pemustaka dan memungkinkan perpustakaan untuk memfokuskan pada masalah serius yang segera perlu ditangani di perpustakaan.

Oleh karena itu, LibQUAL ${ }^{+T M}$ dapat mengidentifikasi apa yang menjadi kekuatan dan kelemahan perpustakaan dilihat dari perspektif pemustakanya. Cook, Heath, and Thompson (2003) dalam Bud (2005: 146) juga menegaskan bahwa alat ukur yang ada dalam LibQUAL ${ }^{+T M}$ dimaksudkan untuk menjadikan suatu mekanisme untuk mendengarkan pemustaka.
Jadi bisa penulis simpulkan bahwa metode LibQUAL $^{+\mathrm{TM}}$ merupakan metode khusus untuk mengukur kualitas layanan di perpustakaan berdasarkan persepsi, harapan minimum, dan harapan ideal pemustakanya.

Dimensi kualitas layanan perpustakaan dan indikator dengan menggunakan metode LibQUAL ${ }^{+\mathrm{TM}}$ dalam penelitian ini seperti terlihat pada Gambar 1.

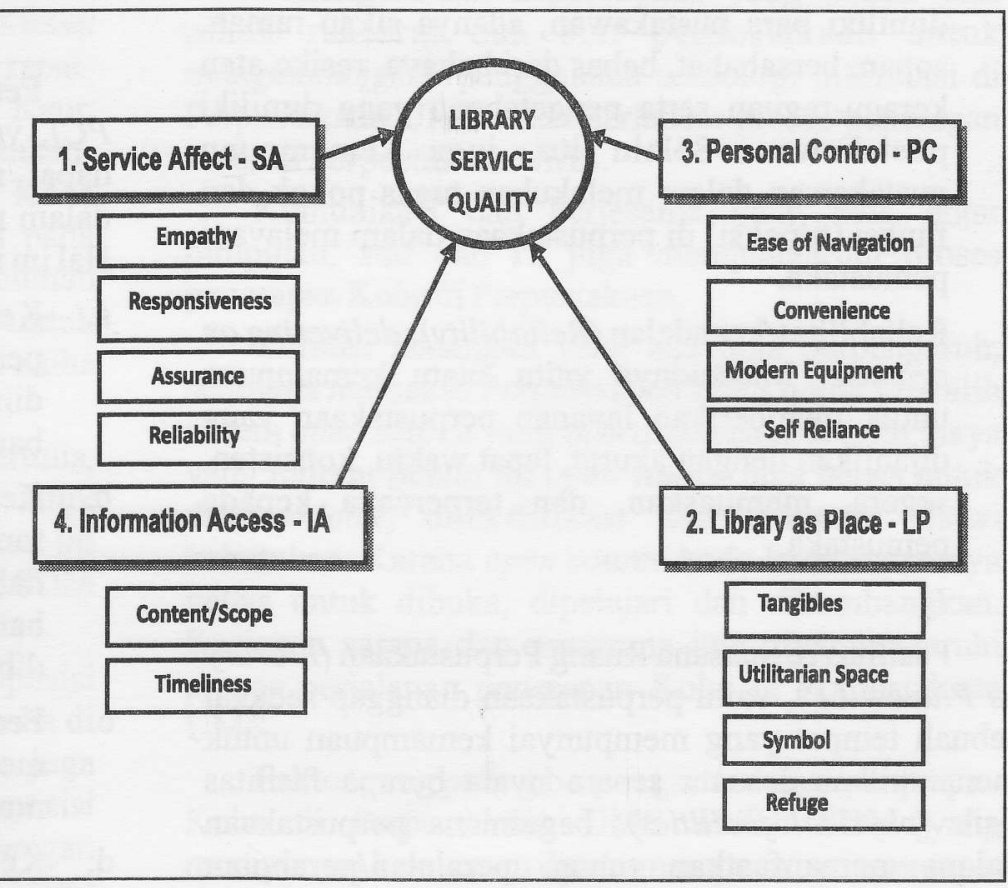

Gambar 1. Dimensi dan Indikator

Kualitas Layanan Perpustakaan

Sumber: Konsep yang dikembangkan oleh penulis (2011), menggunakan referensi dari Dimension of Library Service Quality (Boykin, 2002).

Kemampuan \& Sikap Pustakawan Dalam Melayani (Service Affect - SA) yaitu kemampuan, sikap dan mentalitas pustakawan dalam melayani pemustaka. Kualitas layanan perpustakaan akan menjadi semakin baik apabila pustakawan mempunyai kemampuan sebagai perantara/penengah (intermediary) dan penghubung antara perpustakaan dengan pemustaka (liaison librarian) secara profesional. Dimensi dari Service Affect (SA) meliputi:

a. Empati/kepedulian (Empathy): threating customer as individuals. Memberikan perhatian yang bersifat individual atau pribadi kepada pemustaka dan berupaya untuk memahami keinginan/kebutuhannya yang meliputi 
kemudahan dalam melakukan hubungan komunikasi yang baik.

b. Ketanggapan (Responsiveness): being willing to $h e l p$. Kemauan/kesediaan para pustakawan untuk membantu dan memberikan layanan dengan tanggap dan cepat (responsif) kepada pemustaka.

c. Jaminan/kepastian (Assurance): inspiring truth and confidence. Mencakup keamanan, kesopanan dan keramahan, sifat dapat dipercaya yang dimiliki para pustakawan, adanya sikap ramah, sopan, bersahabat, bebas dari bahaya, resiko atau keragu-raguan serta pengetahuan yang dimiliki pustakawan. Selain itu, juga kemampuan pustakawan dalam melakukan tugas pokok dan fungsi (tupoksi) di perpustakaan dalam melayani pemustaka.

d. Reliabilitas/keandalan (Reliability): delivering on promise. Maksudnya yaitu suatu kemampuan untuk memberikan layanan perpustakaan yang dijanjikan dengan akurat, tepat waktu, konsisten, segera, memuaskan, dan terpercaya kepada pemustaka.

Fasilitas \& Suasana Ruang Perpustakaan (Library as Place - LP), yaitu perpustakaan dianggap sebagai sebuah tempat yang mempunyai kemampuan untuk menampilkan sesuatu secara nyata berupa fasilitas fisik (physical facilities), bagaimana perpustakaan dalam memanfaatkan ruang, peralatan/perabotan (equipment), ketersediaan sarana peralatan komunikasi dan petugas (personnel and communication materials), maupun sebagai simbol dan tempat perlindungan. Konsep library as place digunakan untuk menilai kemampuan perpustakaan dalam memenuhi harapan pemustaka dalam penyediaan berbagai fasilitas di perpustakaan. Aspek dalam library as place adalah:

a. Berwujud/ada bukti fisik (Tangibles): representing the service phisically. Fasilitas fisik dan perlengkapan di perpustakaan, gedung yang bagus dan ber-AC, tersedia fasilitas sarana penelusuran (OPAC), sarana komunikasi (telepon/intercom), tempat parkir yang luas, sarana ibadah, bookstore, peralatan komputer yang canggih, jurnal ilmiah (nasional dan internasional), e-journals, online databases, serta penampilan, cara berkomunikasi, seragam pustakawan yang menarik.

b. Ruang yang bermanfaat (Utilitarian Space), yaitu adanya ruangan di perpustakaan yang bisa dimanfaatkan untuk diskusi dan belajar bagi segenap civitas akademik.

c. Berbagai makna (Symbol) yang nyata, meliputi peralatan, fasilitas fisik, dan peralatan komunikasi yang disediakan di perpustakaan.

d. Tempat belajar yang nyaman (Refuge), meliputi penyediaan ruang belajar yang merangsang kreativitas dan imajinasi, tempat yang kondusif untuk bertumbuh kembangnya pikiran.

Petunjuk \& Sarana Akses (Personal Control $P C$ ), yaitu suatu konsep yang membuat pemustaka dapat melakukan sendiri apa yang diinginkannya dalam mencari informasi tanpa bantuan pustakawan. Hal ini menyangkut aspek:

a. Kemudahan akses (Ease of Navigation), bahwa pemustaka dapat melakukan sendiri apa yang diinginkannya dalam mencari informasi tanpa bantuan pustakawan.

b. Kenyamanan individu pemustaka (Convenience), mencakup kenyamanan waktu yang dibutuhkan dalam mendapatkan informasi dan ketiadaan hambatan dalam mengakses informasi pada saat dibutuhkan.

c. Peralatan yang modern (Modern Equipment), meliputi berbagai fasilitas perpustakaan yang mutakhir dan sesuai kebutuhan pemustaka.

d. Kepercayaan diri (Self Reliance), bahwa pemustaka mempunyai keyakinan dapat menggunakan sarana akses dan berbagai petunjuk penelusuran informasi di perpustakaan.

Akses Informasi (Information Access - IA), yaitu berkaitan dengan ketersediaan bahan perpustakaan yang memadai, kekuatan bahan perpustakaan yang dimiliki, cakupan isi/ruang lingkup, aktualitas, bimbingan pustakawan, maupun tingkat kecepatan waktu akses informasi di perpustakaan. Pada dimensi akses informasi ini meliputi:

a. Isi/ruang lingkup (Content/Scope) mencakup ketersediaan koleksi yang memadai, kekayaan koleksi jurnal full text maupun sumber informasi lainnya yang dimiliki, serta tersedianya bimbingan pemustaka untuk menelusur informasi di perpustakaan.

b. Kecepatan waktu akses (Timeliness) mencakup kemudahan akses untuk menemukan informasi yang relevan dan akurat. 
Dalam menggunakan metode LibQUAL+TM untuk menilai kualitas layanan di perpustakaan, menggunakan rumus:

$$
A G(\text { Adequacy Gap })=\text { Perceived }(P)-\operatorname{Minimum}(M)
$$$$
S G(\text { Superiority Gap })=\text { Perceived }(P)-\text { Desired }(D)
$$

Maksud dari skor AG (Adequacy Gap) dan SG (Superiority Gap) pada rumus tersebut dapat dijelaskan sebagai berikut:

- Adequacy Gap (AG), merupakan nilai selisih yang diperoleh dari persepsi (perceived) dikurangi harapan minimum (minimum). Jadi AG itu bernilai positif, yang berarti responden "cukup puas" jika persepsi > harapan minimum $(\mathrm{P}>\mathrm{HM})$. Apabila skor SG menunjukkan nilai yang positif, hal ini menunjukkan bahwa layanan yang diberikan telah melebihi harapan pemustaka, jadi pemustaka sangat puas terhadap layanan yang diterimanya. Lalu jika skor SG menunjukkan nilai negatif, maka kualitas layanan dinilai baik, berada pada 'zone tolerance', dimana kualitas layanan berada di antara tingkat minimum yang dapat diterima dan tingkat harapan ideal (desired). Zone of tolerance, merupakan suatu wilayah (area) antara tingkat minimum yang bisa diterima dan tingkat harapan ideal (desired). Jadi persepsi pemustaka dikatakan ideal jika berada dalam wilayah "zone of tolerance" ini. Zone of tolerance bisa meningkat maupun menurun, tergantung atribut layanan yang bisa dikendalikan.

- Superiority Gap (SG), merupakan nilai selisih yang diperoleh dari persepsi (perceived) dikurangi harapan ideal (desired). Jadi nilai SG negatif, jika persepsi < harapan ideal $(\mathrm{P}<\mathrm{HI})$. Apabila skor AG menunjukkan nilai positif, artinya bahwa layanan yang diberikan telah melebihi atau memenuhi harapan pemustaka, jadi pemustaka cukup puas terhadap layanan yang diterimanya. Jika skor AG menunjukkan nilai yang negatif, maka layanan yang diberikan belum memenuhi harapan pemustaka, sehingga pemustaka belum atau tidak puas terhadap layanan yang diterimanya.

Penjabaran variabel penelitian dapat dijabarkan dalam kerangka pikir pada Gambar 2.

\section{EVALUASI KUALITAS LAYANAN PERPUSTAKAAN}

\section{Metode LibQUAL ${ }^{+T M}$}

1. Kemampuan \& Sikap Pustakawan dalam Melayani (Service Affect-SA)

2. Fasilitas \& Suasana Ruang Perpustakaan (Library as Place -LP)

3. Petunjuk \& Sarana Akses (Personal Control-PC)

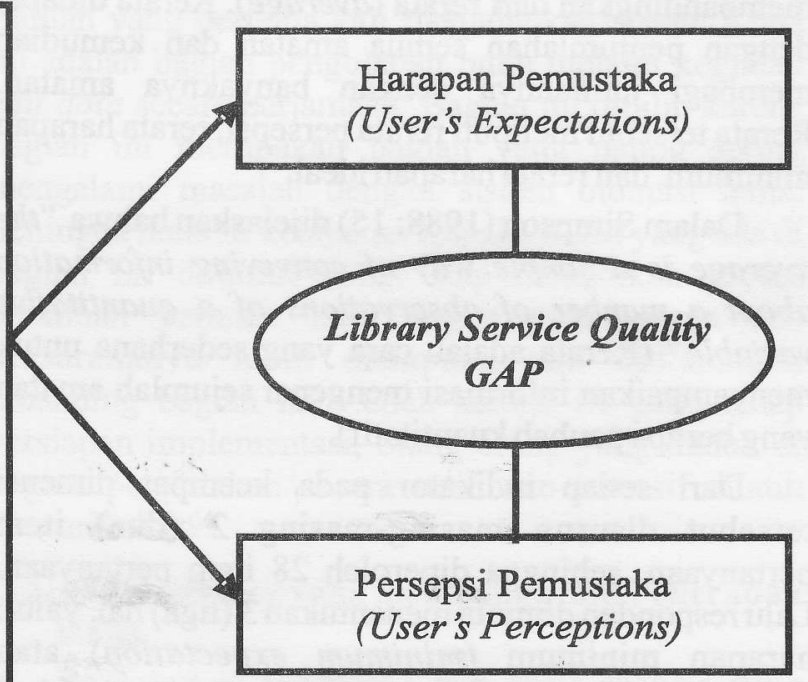

\section{Gambar 2. Kerangka Pikir}

Sumber: Olahan Penulis dikembangkan untuk penelitian, 2011. 


\section{Hipotesis Penelitian}

Ada 8 hipotesis penelitian yang diajukan, yaitu: Service Affect Persepsi (SAP) berbeda dengan Service Affect Minimum (SAM); Service Affect Persepsi (SAP) berbeda dengan Service Affect Ideal (SAI); Library as Place Persepsi (LPP) berbeda dengan Library as Place Minimum (LPM); Library as Place Persepsi (LPP) berbeda dengan Library as Place Ideal (LPI); Personal Control Persepsi (PCP) berbeda dengan Personal Control Minimum (PCM); Personal Control Persepsi (PCP) berbeda dengan Personal Control Ideal (PCI); Information Access Persepsi (IAP) berbeda dengan Information Access Minimum (IAM); Information Access Persepsi (IAP) berbeda dengan Information Access Ideal (IAI).

\section{Metodologi Penelitian}

Desain penelitian yang digunakan dengan metode penelitian survei. Bersifat deskriptif eksploratif, dengan pendekatan menggunakan metode kuantitatif. Penelitian menggunakan metode $\mathrm{LibQUAL}^{+\mathrm{TM}}$, yaitu suatu metode pengukuran kualitas layanan perpustakaan berdasarkan persepsi dan harapan pemustaka. Untuk mengetahui skor variabel dalam kualitas layanan tersebut, dengan cara membandingkan dari rerata (average). Rerata didapat dengan penjumlahan semua amatan dan kemudian membagi jumlahnya dengan banyaknya amatan. Rerata tersebut meliputi rerata persepsi, rerata harapan minimum, dan rerata harapan ideal.

Dalam Simpson (1988: 15) dijelaskan bahwa "the average is a simple way of conveying information about a number of observations of a quantitative variable" (Rerata adalah cara yang sederhana untuk menyampaikan informasi mengenai sejumlah amatan yang berupa peubah kuantitatif).

Dari setiap indikator pada keempat dimensi tersebut disusun masing-masing 2 (dua) item pertanyaan, sehingga diperoleh 28 item pertanyaan. Lalu responden diminta menentukan 3 (tiga) hal, yaitu: harapan minimum (minimum expectation) atau biasanya disebut minimum saja, harapan ideal (desired), dan persepsi (perceived) dengan memberikan skala nilai 1-9. Maksud dari skala 1 sampai 9 mengandung makna bahwa: nilai terendah $($ low $)=1$, dan nilai tertinggi $($ high $)=9$.

Jenis penelitian menggunakan pendekatan analisis deskriptif, yaitu salah satu teknik statistik yang memberikan informasi hanya mengenai data yang dimiliki. Penelitian berjenis penelitian evaluasi formatif, karena menekankan pada proses dan bertujuan untuk menjelaskan suatu keadaan. Lokasi penelitian ini dilakukan di Perpustakaan FEB UNDIP yang beralamat di Jl. Prof. Soedharto, SH, Kampus Tembalang, Semarang 50275. Subyeknya adalah pemustaka di Perpustakaan FEB UNDIP yang dibatasi hanya mahasiswa. Sementara itu, obyek penelitiannya adalah harapan dan persepsi pemustaka terhadap kualitas layanan di bagian layanan referensi dan sirkulasi Perpustakaan FEB UNDIP.

Objek penelitian ditinjau dari status ontologisnya "konkrit" dan bersifat "objektif empirik". Pemilihan obyek penelitian didasarkan pada pertimbangan bahwa bagian layanan referensi dan sirkulasi merupakan ujung tombak layanan perpustakaan, karena merupakan layanan yang langsung berhadapan dengan pemustaka.

Mahasiswa merupakan obyek dari penelitian ini. Populasi penelitian ini adalah pemustaka FEB UNDIP angkatan tahun akademik 2009/2010 yang terkelompok menjadi 3 kelompok program, yaitu mahasiswa Reguler I, Reguler II, dan Diploma Tiga yang berjumlah 430 orang. Teknik pengambilan sampel dalam penelitian ini dilakukan dengan teknik penarikan contoh acak berstrata proporsional (proporsional stratified random sampling) dengan sampel penelitian berjumlah 81 orang.

Definisi konseptual variabel dari kualitas layanan perpustakaan merupakan standar proses yang harus dilaksanakan dalam suatu kegiatan layanan guna memenuhi harapan/tuntutan pemustaka. Kualitas layanan dapat dilihat dari selisih (gap) antara skor harapan minimum (minimum), harapan ideal (desired) dan persepsi (perceived) dari pemustakanya.

\section{Hasil Pembahasan}

Berdasarkan data yang didapat dari kuesioner yang dibagikan kepada 81 responden, maka dapat diketahui bahwa jenis kelamin dari 35 responden atau 43,2 \% adalah laki-laki dan 46 responden atau 56,8 \% adalah wanita. Pada kelompok jurusan, responden yang paling banyak berkunjung ke Perpustakaan FEB UNDIP adalah dari jurusan Akuntansi untuk ketiga program, sedangkan yang paling sedikit adalah jurusan IESP untuk program S1 dan jurusan Manajemen Perusahaan untuk program Diploma.

Harapan responden diketahui dari jawaban 4 (empat) pertanyaan, mengenai: alasan responden berkunjung ke perpustakaan, waktu buka perpustakaan yang diinginkan responden dalam seminggu, jam buka layanan perpustakaan yang 
diinginkan setiap harinya, dan tingkat kunjungan responden ke perpustakaan.

Berkaitan dengan kebutuhan responden, maka sebanyak $12,3 \%$ (10 orang) menyatakan untuk menambah wawasan, $61,7 \%(50)$ orang untuk mencari literatur, dan $6,2 \%$ (5 orang) masuk dalam kategori lain-lain. Kategori lain-lain yang dimaksud adalah sekedar baca-baca, lihat-lihat, refreshing, memanfaatkan waktu luang, dan ada yang menjawab hanya ingin 'ngadem' saja. Sementara ada 19,8 \% (16 orang) yang menyatakan untuk menambah wawasan dan mencari literatur.

Mengenai harapan responden terhadap waktu buka layanan, maka diperoleh data bahwa sebanyak $22,2 \%$ (18 orang) tetap mengharapkan waktu buka layanan Perpustakaan FEB UNDIP buka 6 (enam) hari dalam seminggu. Sementara hanya $4,9 \%$ (4 orang) saja yang mengharapkan buka 5 (lima) hari dalam seminggu, dan responden tidak ada yang mengharapkan di luar pilihan tersebut. Kemudian sisanya sebanyak $72,9 \%$ (59 orang) yang mengharapkan waktu buka layanan Perpustakaan FEB UNDIP buka penuh, yaitu 7 (tujuh) hari dalam seminggu. *

Apabila dikaitkan dengan harapan dari 81 responden tentang jam buka layanan Perpustakaan FEB UNDIP, maka diketahui bahwa sebanyak 13,6\% (11 orang) responden mengharapkan jam buka layanan pukul 08.00 - 17.30 WIB, kemudian $80,2 \%$ (65 orang) responden mengharapkan jam buka layanan pukul $08.00-19.30 \mathrm{WIB}$, dan yang mengharapkan jam buka layanan pukul $08.00-16.00$ WIB tidak ada. Sementara itu, ada $6,2 \%$ (5 orang) yang mengisi sesuai keinginan dengan mengharapkan jam buka layanan Perpustakaan FEB UNDIP selama 24 jam. Dari kelima responden tersebut, malah ada satu yang mengomentari dalam kurung "Masak jam buka layanan perpustakaan kalah dengan Apotik K-24...?"

Pada frekuensi kunjungan ke Perpustakaan FEB UNDIP, hasilnya menunjukkan bahwa ternyata kebutuhan responden terhadap perpustakaan sangat tinggi. Hal ini berdasarkan data yang diperoleh menunjukkan bahwa responden sebanyak $100 \%$ (81 orang) memilih jawaban 'setiap hari/sering sekali". Berarti responden memiliki kecenderungan persepsi yang baik terhadap layanan Perpustakaan FEB UNDIP dan sangat mengharapkan waktu dan jam buka layanan Perpustakaan FEB UNDIP dapat ditambah atau diperpanjang.

Lalu mengenai komentar/saran/kritik terhadap layanan Perpustakaan FEB UNDIP, inti dari harapan responden adalah mengharapkan peningkatan kualitas layanannya, baik itu meliputi mutu layanan pustakawan maupun peningkatan fasilitas penunjang perpustakaan. Misalnya: tersedianya fasilitas foto kopi, ruang baca yang bersofa, colokan listrik yang ada di setiap meja baca.

Hasil uji statistik validitas diketahui ternyata $r$ hitung (corrected item-total correlation) dari keseluruhan item menunjukkan angka lebih besar dari $r$ tabel $(0,186)$. Jadi dapat disimpulkan bahwa keseluruhan item alat ukur adalah valid. Sementara dari hasil pengolahan data uji reliabilitas, nilai cronbach alpha 0 dari keseluruhan variabel ternyata $>$ 0,60 . Sehingga dapat disimpulkan bahwa semua butir pertanyaan yang dipakai sebagai alat ukur pada penelitian ini adalah reliabel.

\section{Analisis Secara Umum}

Analisis secara umum didapat dengan cara menjumlahkan semua skor persepsi (perceived), harapan minimum (minimum), dan harapan ideal (desired), kemudian dibagi dengan jumlah butir pertanyaan untuk mendapatkan nilai rata-rata persepsi, harapan minimum (minimum), dan harapan ideal (desired).

Hasil perhitungan menunjukkan bahwa nilai ratarata persepsi (perceived) yaitu 5,63 dan nilai rata-rata harapan minimum (minimum) yaitu 4,59, sedangkan nilai rata-rata harapan ideal (desired) yaitu 7,47. Dengan demikian dapat diketahui bahwa nilai rata-rata persepsi lebih tinggi dari harapan minimum, sehingga diperoleh nilai kesenjangan AG (Adequacy Gap) positif yaitu 1,04 dan nilai SG (Superiority Gap) negatif yaitu $-1,84$. Lebih jelas mengenai hasil analisis data secara umum dapat dilihat pada Tabel 1.

Tabel 1. Hasil Analisis Secara Umum

\begin{tabular}{|l|l|l|l|l|l|}
\hline $\begin{array}{c}\text { Pertanyaan (28 butir) } \\
\text { \& Reponden } \\
\text { (81 orang) }\end{array}$ & $\begin{array}{c}\text { Persepsi } \\
\text { (Perceived) }\end{array}$ & $\begin{array}{c}\text { Marapan } \\
\text { Minimum } \\
\text { (Minimum) }\end{array}$ & $\begin{array}{c}\text { Marspan } \\
\text { Ideal } \\
\text { (Desired) }\end{array}$ & $\begin{array}{c}\text { Adequ-acy } \\
\text { Gop (AG) }\end{array}$ & $\begin{array}{c}\text { Supperi-oriby } \\
\text { Gap (SG) }\end{array}$ \\
\hline Rata-rata & 5,63 & 4,59 & 7,47 & 1,04 & $-1,84$ \\
\hline
\end{tabular}

Sumber: Data primer diolah, 2011. 
Berdasarkan pada Tabel 1 diketahui bahwa hasil AG skornya positif, maka dapat diinterpretasikan bahwa layanan Perpustakaan FEB UNDIP dapat memenuhi harapan minimum pemustaka. Maksudnya bahwa pemustaka "cukup puas" dengan layanan yang diberikan. Selanjutnya hasil SG skornya negatif, maka hal ini berarti dapat diinterpretasikan kalau kualitas layanan Perpustakaan FEB UNDIP berada pada wilayah yang disebut dengan "batas toleransi (zone of tolerance)".

Jadi angka 1,04 tersebut menunjukkan bahwa Adequacy Gap ( $A G$ ) adalah positif dan berada pada wilayah 'zone of tolerance'. Hal ini berarti bahwa kualitas layanan Perpustakaan FEB UNDIP masih dalam batas toleransi atau dinyatakan baik.

Hal tersebut juga menunjukkan bahwa pemustaka Perpustakaan FEB UNDIP menilai kualitas layanan yang diterimanya telah memenuhi harapan minimum yang diinginkan. Maka dari itu, pemustaka dapat dinyatakan 'puas' dengan layanan yang $\mathrm{d} \mathrm{i} \mathrm{b} \mathrm{e} \mathrm{r} \mathrm{i} \mathrm{k} \mathrm{a} \mathrm{n}$. Berdasarkan hasil analisis secara umum tersebut, berarti dapat dikatakan bahwa secara umum pula kalau kualitas layanan Perpustakaan FEB UN D I P s udah ' $\mathrm{m}$ e mua s ka n' pemustakanya. Namun demikian ternyata hasilnya juga masih berada di bawah harapan ideal.

\section{Analisis Berdasarkan Dimensi Kualitas Layanan Perpustakaan}

Analisis berdasarkan dimensi kualitas layanan ini diperoleh dengan cara menjumlahkan semua skor persepsi (perceived), semua skor harapan minimum (minimum), dan semua skor harapan ideal (desired).

Langkah selanjutnya lalu masing-masing skor tersebut dibagi dengan jumlah butir pertanyaan pada masing-masing dimensi.
Dengan demikian, akan dapat diketahui nilai rata-rata persepsi, nilai rata-rata harapan minimum, dan nilai rata-rata harapan idealnya. Berdasarkan pada Tabel 2 diketahui bahwa nilai rata-rata harapan pada dimensi Service Affect (SA) adalah 36,44 untuk minimum, sedangkan 59,46 untuk ideal. Selanjutnya nilai rata-rata persepsinya 43,85 , yang berarti lebih besar dari nilai rata-rata harapan minimum. Lalu dapat diketahui angka kesenjangan Adequacy Gap $(A G)$ yaitu 7,407. Angka 7,407 tersebut menunjukkan bahwa AG-nya adalah "positif". Hal ini berarti bahwa responden sudah 'cukup puas' dengan layanan perpustakaan pada dimensi Service Affect (SA).

Begitu juga hal yang sama terjadi pada ketiga dimensi lainnya, yaitu Library as Place (LP), Personal Control (PC), dan Information Access (IA), dimana responden ternyata 'cukup puas' dengan layanan

\begin{tabular}{|l|c|c|c|c|c|}
\hline $\begin{array}{c}\text { Dimensi Kualitas } \\
\text { Layanan Perpustakaan }\end{array}$ & $\begin{array}{c}\text { Persepsi } \\
\text { (Perceived) }\end{array}$ & $\begin{array}{c}\text { IIarapan } \\
\text { Minimum } \\
\text { (Minimum) }\end{array}$ & $\begin{array}{c}\text { Mlarapan } \\
\text { Ideal } \\
\text { (Desired) }\end{array}$ & $\begin{array}{c}\text { Adequacy } \\
\text { Gap (AG) }\end{array}$ & $\begin{array}{c}\text { Superiority } \\
\text { Gap (SG) }\end{array}$ \\
\hline $\begin{array}{l}\text { Kemampuan \& Sikap } \\
\text { Pustakawan Dalam } \\
\text { Melayani (Service Affect - } \\
\text { SA). }\end{array}$ & 43,85 & 36,44 & 59,46 & 7,407 & $-15,605$ \\
\hline $\begin{array}{l}\text { Fasilitas \& Suasana Ruang } \\
\text { Perpustakaan (Library as } \\
\text { Place - LP). }\end{array}$ & 46,90 & 37,83 & 59,30 & 9,074 & $-12,395$ \\
\hline $\begin{array}{l}\text { Petunjuk \& Sarana Akses } \\
\text { (Personal Control - PC). }\end{array}$ & 44,33 & 36,72 & 60,22 & 7,617 & $-15,889$ \\
\hline $\begin{array}{l}\text { Akses Informasi } \\
\text { (Information Access - IA). }\end{array}$ & 22,59 & 17,43 & 30,05 & 5,160 & $-7,457$ \\
\hline
\end{tabular}

Tabel 2. Nilai Rata-Rata Persepsi, Harapan Minimum, Harapan Ideal Berdasarkan Dimensi Sumber: Data primer diolah, 2011

Perpustakaan FEB UNDIP. Selain itu, nampak terlihat bahwa dimensi yang paling cukup memuaskan adalah dimensi Library as Place-LP $(\mathrm{AG}=9,074)$, lalu dimensi Personal Control-PC $(\mathrm{AG}=7,617)$, disusul dimensi Service Affect-SA (AG $=7,407)$, dan kemudian yang terakhir adalah dimensi Information Access- $L A$ ( $\mathrm{AG}=5,160)$. Jadi dengan demikian, dimensi Library as Place-LP adalah dimensi yang paling baik atau paling lumayan, sementara dimensi Information Access- $I A$ adalah dimensi yang paling jelek.

Selanjutnya jika dilihat dari skor nilai rata-rata kesenjangan Superiority Gap (SG) nampak bahwa nilai pada keempat dimensi adalah "negatif". Artinya bahwa kualitas layanan Perpustakaan FEB UNDIP masih dalam batas yang "bisa ditoleransi atau baik" . Alasannya karena hasilnya ternyata sudah berada pada 
wilayah batas toleransi (zone of tolerance). Pada Tabel 2 tersebut terlihat bahwa dimensi yang paling bisa ditoleransi atau baik adalah pada dimensi Information Access-IA ( $\mathrm{SG}=-7,457)$, lalu dimensi Library as Place-LP (SG $=-12,395)$, disusul dimensi Service Affect-SA ( $S G=-15,605)$, dan yang terakhir adalah dimensi Personal Control-PC $(\mathrm{SG}=-15,889)$. Hal ini berarti dimensi Information Access-IA adalah yang paling mendekati harapan, sedangkan dimensi Personal Control-PC adalah dimensi yang paling jauh dari harapan atau paling buruk.

\section{Analisis Berdasarkan Indikator Kualitas Layanan Perpustakaan}

Analisis berdasarkan indikator merupakan analisis yang dilakukan terhadap 14 indikator dalam kuesioner. Lebih jelasnya mengenai nilai rata-rata perindikator pada masing-masing dimensi dalam variabel penelitian ini dapat dilihat pada Tabel 3 sampai 6 .

Tabel 3. Nilai Rata-Rata Per-Indikator Pada Dimensi Kemampuan \& Sikap Pustakawan dalam Melayani (Service Affect - SA)

\begin{tabular}{|l|l|l|l|l|l|}
\hline \multicolumn{1}{|c|}{ Indikator } & $\begin{array}{c}\text { Persepsi } \\
\text { (Perceived) }\end{array}$ & $\begin{array}{c}\text { Itarapan } \\
\text { Minimum } \\
\text { (Minimum) }\end{array}$ & $\begin{array}{c}\text { Harapan } \\
\text { Ideal } \\
\text { (Desired) }\end{array}$ & $\begin{array}{c}\text { Adequacy } \\
\text { Gag (AG) }\end{array}$ & $\begin{array}{c}\text { Superionity } \\
\text { Gepp } \\
\text { (SG) }\end{array}$ \\
\hline $\begin{array}{l}\text { Empati/ } \\
\text { kepeduli an } \\
\text { (Empathy) }\end{array}$ & 10,37 & 8,89 & 14,54 & 1,481 & $-4,173$ \\
\hline $\begin{array}{l}\text { Ketanggapan } \\
\text { (Responsiven } \\
\text { ess) }\end{array}$ & 10,47 & 9,12 & 14,96 & 1,346 & $-4,494$ \\
\hline $\begin{array}{l}\text { Jaminan/kepa } \\
\text { stian } \\
\text { (Assurance) }\end{array}$ & 11,51 & 9,21 & 14,65 & 2,296 & $-3,148$ \\
\hline $\begin{array}{l}\text { Reliabilitas/k } \\
\text { eanda-lan } \\
\text { (Reliability) }\end{array}$ & 11,51 & 9,22 & 15,30 & 2,284 & $-3,790$ \\
\hline
\end{tabular}

Sumber: Data primer diolah, 2011.

Berdasarkan pada Tabel 3 berarti bahwa penilaian responden "paling cukup puas" terhadap dimensi kemampuan \& sikap pustakawan dalam melayani adalah yang skornya paling tinggi yaitu pada indikator jaminan/kepastian (assurance).

Namun demikian, ternyata apabila dilihat dari skor nilai SGnya, maka menjadi kebalikannya. Paling tinggi adalah - 4,494 pada indikator ketanggapan (responsiveness), dan yang paling rendah adalah sebesar - 3,148 pada indikator jaminan/kepastian (assurance). Jadi indikator ketanggapan (responsiveness) merupakan kualitas layanan "paling bisa ditoleransi atau baik" pada dimensi kemampuan \& sikap pustakawan dalam melayani (Service Affect $S A)$.
Tabel 4. Nilai Rata-Rata Per-Indikator pada Dimensi Fasilitas \& Suasana Ruang Perpustakaan (Library as Place - LP)

\begin{tabular}{|c|c|c|c|c|c|}
\hline Indilkator & $\begin{array}{l}\text { Persepsi) } \\
\text { (Perceived) }\end{array}$ & $\begin{array}{l}\text { Anarapan } \\
\text { Winimaumia } \\
\text { (Mrinimem) }\end{array}$ & 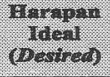 & $\begin{array}{l}\text { Adequeds) } \\
\text { Gep }(1 \mathrm{c})\end{array}$ & $\begin{array}{l}\text { Superiority } \\
\text { Cuys } \\
\text { (a) }\end{array}$ \\
\hline $\begin{array}{l}\text { Berwujud/ada } \\
\text { bukti fisik } \\
\text { (Tangibles) }\end{array}$ & 11,59 & 9,53 & 14,91 & 2,062 & $-3,321$ \\
\hline $\begin{array}{l}\text { Ruang yang } \\
\text { bermanfaat } \\
\text { (Utilitarian } \\
\text { Space) }\end{array}$ & 11,75 & 9,43 & 14,54 & 2,321 & $-2,790$ \\
\hline $\begin{array}{l}\text { Berbagai } \\
\text { makna } \\
\text { (Symbol) }\end{array}$ & 11,90 & 9,27 & 14,80 & 2,630 & $-2,901$ \\
\hline $\begin{array}{l}\text { Tempat belajar } \\
\text { yang nyaman } \\
\text { (Refuge) }\end{array}$ & 11,65 & 9,59 & 15,04 & 2,062 & $-3,383$ \\
\hline
\end{tabular}

Sumber: Data primer diolah, 2011.

Pada Tabel 4 terlihat bahwa skor AG tertinggi sebesar 2,630 pada indikator berbagai makna (symbol), dan yang terendah sebesar 2,062 ada pada 2 (dua) indikator, yaitu berwujud/ada bukti fisik (tangibles) dan tempat belajar yang nyaman (refuge). Artinya bahwa responden yang "paling cukup puas" terhadap dimensi fasilitas \& suasana ruang perpustakaan (Library as Place - LP) adalah pada indikator berbagai makna (symbol).

Selanjutnya nilai SG paling besar adalah $-3,383$ pada indikator tempat belajar yang nyaman (refuge), dan yang paling kecil sebesar - 2,790 pada ruang yang bermanfaat (utilitarian space). Hal ini menunjukkan bahwa kualitas layanan pada dimensi fasilitas \& suasana ruang perpustakaan (Library as Place - LP) yang "paling bisa ditolerir paling baik" adalah pada indikator tempat belajar yang nyaman (refuge).

Memang saat ini di Perpustakaan FEB UNDIP karena menempati gedung yang baru, maka ruangan perpustakaannya juga sangat kondusif sebagai tempat untuk belajar. Disamping luas juga dirancang dengan konsep "learning commons", sehingga pemustaka sangat nyaman dan senang berlama-lama di Perpustakaan FEB UNDIP. 
Tabel 5.

Nilai Rata-Rata Per-Indikator pada Dimensi Petunjuk \& Sarana Akses (Personal Control - PC)

\begin{tabular}{|c|c|c|c|c|c|}
\hline Indikator & $\begin{array}{l}\text { Persepsi } \\
\text { (Perceived) }\end{array}$ & $\begin{array}{l}\text { Trarapan } \\
\text { Minimum } \\
\text { (Minimum) }\end{array}$ & $\begin{array}{c}\text { Harapan } \\
\text { Ideal } \\
\text { (Desired) }\end{array}$ & $\begin{array}{l}\text { Adequacy } \\
\text { Cup } \\
(A G)\end{array}$ & $\begin{array}{c}\text { Supperiority } \\
\text { Gapj } \\
\text { (SGG) }\end{array}$ \\
\hline $\begin{array}{l}\text { Kemudahan } \\
\text { akses (Ease of } \\
\text { Navigation) }\end{array}$ & 11,32 & 9,20 & 14,99 & 2,123 & $-3,667$ \\
\hline $\begin{array}{l}\text { Kenyamanan } \\
\text { individu } \\
\text { pemustaka } \\
\text { (Convenience) }\end{array}$ & 11,40 & 9,20 & 15,09 & 2,198 & $-3,691$ \\
\hline $\begin{array}{l}\text { Peralatan } \\
\text { yang modern } \\
\text { (Modern } \\
\text { Equipment) }\end{array}$ & 10,56 & 9,12 & 15,26 & 1,432 & $-4,704$ \\
\hline $\begin{array}{l}\text { Kepercayaan } \\
\text { diri (Self } \\
\text { Reliance) }\end{array}$ & 11,06 & 9,20 & 14,89 & 1,864 & $-3,827$ \\
\hline
\end{tabular}

Sumber: Data primer diolah, 2011

Pada Tabel 5 nampak bahwa skor AG yang paling tinggi pada indikator kenyamanan individu pemustaka (convenience) yaitu sebesar 2,198, sedangkan yang terendah sebesar 1,432 pada peralatan yang modern (modern equipment). Hal ini menunjukkan bahwa pada dimensi petunjuk \& sarana akses (Personal Control - PC), responden "paling cukup puas" terhadap indikator kenyamanan individu pemustaka (convenience). Hal ini berarti adanya petunjuk atau panduan dari penggunaan fasilitas layanan di Perpustakaann FEB UNDIP sangat membantu pemustaka, sehingga pemustaka merasa nyaman. Selain itu, dapat diinterpretasikan juga bahwa pemustaka ternyata nyaman dengan waktu yang dibutuhkan dalam mendapatkan informasi di Perpustakaan FEB UNDIP.

Sedang nilai SG yang paling besar adalah sebesar - 4,704 pada indikator peralatan yang modern (modern equipment), dan yang nilainya paling kecil pada indikator kemudahan akses (ease of navigation) sebesar - 3,667. Hal ini berarti bahwa kualitas layanan pada dimensi petunjuk \& sarana akses (Personal Control $-P C$ ), yang "paling bisa ditoleransi atau baik" adalah pada indikator peralatan yang modern (modern equipment).
Tabel 6.

Nilai Rata-Rata Per-Indikator pada Dimensi Akses Informasi (Information Access - IA)

\begin{tabular}{|c|c|c|c|c|c|}
\hline Indilkator & $\begin{array}{c}\text { Persepsi } \\
\text { (Perceived) }\end{array}$ & $\begin{array}{l}\text { Rarapan } \\
\text { Minimuma } \\
\text { (Mtistivum) }\end{array}$ & $\begin{array}{l}\text { Alarapan } \\
\text { Ideal } \\
\text { (Desired) }\end{array}$ & $\begin{array}{l}\text { Adequacy } \\
\text { Gep }(A G)\end{array}$ & $\begin{array}{c}\text { superiority } \\
\text { Capp } \\
(S G)\end{array}$ \\
\hline $\begin{array}{l}\text { Isi/ruang } \\
\text { lingkup } \\
\text { (Content/ } \\
\text { Scope) }\end{array}$ & 11,64 & 8,96 & 14,85 & 2,679 & $-3,210$ \\
\hline $\begin{array}{l}\text { Kecepatan } \\
\text { waktu akses } \\
\text { (Timeliness) }\end{array}$ & 10,95 & 8,47 & 15,20 & 2,481 & $-4,247$ \\
\hline
\end{tabular}

Sumber: Data primer diolah, 2011.

Berdasarkan pada Tabel 6 dapat diketahui bahwa skor AG yang tinggi sebesar 2,679 pada indikator isi/ruang lingkup content/scope), dan yang rendah sebesar 2,481 pada kecepatan waktu akses (timeliness). Artinya bahwa responden dalam menilai dimensi akses informasi yang "paling cukup puas" adalah pada indikator isi/ruang lingkup content/scope).

Nilai SG yang paling besar nampak pada indikator kecepatan waktu akses (timeliness) sebesar - 4,247, dan yang paling kecil adalah - 3,210 pada indikator isi/ruang lingkup (content/scope). Jadi kualitas layanan pada dimensi akses informasi yang "paling bisa ditoleransi atau baik" adalah pada indikator kecepatan waktu akses (timeliness).

\section{Analisis Berdasarkan Butir Pertanyaan}

Analisis berdasarkan butir pertanyaan adalah analisis yang dilakukan terhadap 28 butir pertanyaan dalam kuesioner. Dalam melakukan analisis berdasarkan butir pertanyaan ini, dapat diketahui angka kesenjangan (gap score) yang bervariasi. Analisis Adequacy Gap ( $A G)$ dengan melihat secara rinci masing-masing butir pertanyaan pada masingmasing dimensi, maka dimensi yang paling banyak berkontribusi memuaskan responden adalah dimensi Library as Place (LP).

Alasannya karena kedelapan butir pertanyaan yang ada dalam dimensi Library as Place (LP) ini mempunyai nilai $A G$ positif paling besar, yaitu sebesar 9,074. Lebih jelas mengenai hasil analisis SG dan AG berdasarkan pada setiap butir pertanyaan pada keempat dimensi seperti pada Tabel 7, (halaman 12)

Apabila nilai Adequacy Gap ( $A G$ ) dilihat dari setiap butir pertanyaan, maka pada Tabel 9, terlihat bahwa nilai AG yang paling besar nampak pada butir pertanyaan nomor 26 sebesar 1,68. Butir pertanyaannya mengenai tersedia bimbingan pemustaka pada saat dibutuhkan. Artinya bahwa butir pertanyaan nomor 26 tersebut merupakan pertanyaan yang pemustaka merasa "paling cukup puas". Jadi adanya bimbingan pemustaka oleh pustakawan yang disediakan oleh Perpustakaan FEB UNDIP ternyata 
membuat pemustaka menjadi cukup puas, sehingga pemustaka merasa senang ada layanan bimbingan pemustaka tersebut. Maka dari itu, bimbingan pemustaka yang saat ini ada di Perpustakaan FEB UNDIP perlu dipertahankan keberadaannya.

Untuk nilai AG yang paling kecil sebesar 0,46 pada butir pertanyaan nomor 4 , yaitu mengenai pustakawan selalu tanggap memberikan bantuan dalam mencari informasi yang diperlukan pemustaka. Artinya bahwa butir pertanyaan nomor 4 tersebut mengindikasikan "cukup puas yang paling rendah". Jadi pemustaka ternyata menilai bahwa pustakawan di Perpustakaan FEB UNDIP dalam memberikan layanan masih belum memuaskan pemustaka. Hal ini disebabkan pustakawan tidak selalu tanggap saat pemustaka memerlukan bantuan dalam mencari informasi di Perpustakaan FEB UNDIP.

Selanjutnya apabila dilakukan analisis pada Superiority Gap (SG) dengan melihat secara rinci masing-masing butir pertanyaan pada masing-masing dimensi, maka dimensi yang paling banyak dalam batas toleransi responden adalah dimensi Personal Control (PC). Alasannya karena kedelapan butir pertanyaan yang ada dalam dimensi Personal Control $(P C)$ ini mempunyai nilai SG paling besar, yaitu 15,889 .

Nilai SG yang paling besar nampak pada butir pertanyaan nomor 21 yaitu mengenai ketersediaan fasilitas mesin foto kopi dalam membantu responden memperoleh bahan perpustakaan yang dibutuhkan.
Nilai SG pada pertanyaan nomor 21 tersebut - 2,60. Hal ini berarti bahwa butir pertanyaan nomer 21 tersebut adalah yang. "paling belum bisa ditoleransi atau belum baik". Oleh karena itu pihak Perpustakaan FEB UNDIP perlu memfasilitasi dengan menyediakan mesin foto kopi di perpustakaan. Kenyataannya memang saat ini di Perpustakaan FEB UNDIP belum ada mesin foto kopi, sehingga jika pemustaka ingin memfotokopi harus membawa bahan perpustakaan yang mau difotokopi dengan mencari di luar perpustakaan.

Sementara, nilai SG yang paling kecil sebesar 1,20 nampak sama nilainya pada butir pertanyaan nomor 12 dan 26. Pertanyaan nomor 12 tentang desain ruangan sebagai tempat diskusi yang menarik minat pemustaka, sedangkan pertanyaan nomor 26 tentang tersedianya bimbingan pemustaka saat dibutuhkan. Hal ini dapat diinterpretasikan bahwa tersedianya ruangan sebagai tempat diskusi yang menarik bagi pemustaka dan tersedianya bimbingan pemustaka saat dibutuhkan dinilai "paling bisa ditoleransi atau baik" oleh pemustaka.

Kondisi saat ini memang di Perpustakaan FEB UNDIP semenjak pindah lokasi di kampus Tembalang, maka tersedia ruang baca dan ruangan diskusi yang sangat luas dan nyaman untuk pemustaka. Selain itu, para pustakawan di masing-masing konter layanan juga bisa berperan langsung sebagai pemandu untuk bimbingan pemustaka yang mengalami kesulitan dalam penelusuan informasi di perpustakaan.

Tabel 7. Skor SG dan AG Berdasarkan Butir Pertanyaan

\begin{tabular}{|c|c|c|c|c|c|c|c|}
\hline INDIKATOR & No & JENIS PERTANYAAN & P & $\mathbf{H M}$ & HII & \multirow{2}{*}{$\begin{array}{l}\text { Superiority } \\
\text { Gap (SG) }\end{array}$} & \multirow{2}{*}{$\begin{array}{l}\text { Adequacy } \\
\text { Gap }(A G)\end{array}$} \\
\hline \multicolumn{3}{|c|}{$\begin{array}{l}\text { Kemampuan \& Sikap Pustakawan Dalam Melayani } \\
\text { (Service Affect - SA) }\end{array}$} & & & & & \\
\hline \multirow{2}{*}{$\begin{array}{l}\text { Empati/ } \\
\text { kepedulian } \\
\text { (Empathy) }\end{array}$} & $\begin{array}{c}\text { Emp1 } \\
(1)\end{array}$ & $\begin{array}{l}\text { Pustakawan memahami } \\
\text { kebutuhan saya di perpustakaan. }\end{array}$ & 5,33 & 4,37 & 7,15 & $-1,80$ & 0,96 \\
\hline & Emp2 & $\begin{array}{l}\text { Pustakawan memberikan } \\
\text { perhatian yang sungguh-sungguh } \\
\text { kepada saya. }\end{array}$ & $\begin{array}{c}5,04 \\
\text { (terendah) }\end{array}$ & 4,52 & 7,40 & $-2,40$ & 0,52 \\
\hline \multirow{2}{*}{$\begin{array}{l}\text { Ketanggapan } \\
\text { (Responsive- } \\
\text { ness) }\end{array}$} & $\begin{array}{c}\operatorname{Res} 3 \\
(3)\end{array}$ & $\begin{array}{l}\text { Kesediaan pustakawan untuk } \\
\text { membantu kesulitan saya di } \\
\text { perpustakaan. }\end{array}$ & 5,36 & 4,47 & 7,52 & $-2,20$ & 0,89 \\
\hline & $\begin{array}{c}\operatorname{Res} 4 \\
(4)\end{array}$ & $\begin{array}{l}\text { Pustakawan selalu tanggap } \\
\text { memberikan bantuan dalam } \\
\text { mencari informasi yang saya } \\
\text { perlukan. }\end{array}$ & 5,11 & 4,65 & 7,44 & $-2,30$ & $\begin{array}{c}0,46 \\
\text { (terendah) }\end{array}$ \\
\hline \multirow{2}{*}{$\begin{array}{l}\text { Jaminan/ } \\
\text { kepastian } \\
\text { (Assurance) }\end{array}$} & $\begin{array}{l}\text { Ass5 } \\
(5)\end{array}$ & $\begin{array}{l}\text { Keramahan pustakawan dalam } \\
\text { melayani saya. }\end{array}$ & 5,68 & 4,57 & 7,36 & $-1,70$ & 1,11 \\
\hline & $\begin{array}{l}\text { Ass6 } \\
(6)\end{array}$ & $\begin{array}{l}\text { Pustakawan dapat dipercaya } \\
\text { karena memiliki pengetahuan } \\
\text { dalam bidangnya. }\end{array}$ & 5,83 & 4,64 & 7,30 & $-1,50$ & 1,19 \\
\hline \multirow{2}{*}{$\begin{array}{l}\text { Reliabilitas/ } \\
\text { keandalan } \\
\text { (Reliability) }\end{array}$} & $\begin{array}{c}\text { Rel7 } \\
(7)\end{array}$ & $\begin{array}{l}\text { Waktu layanan perpus takaan } \\
\text { sesuai dengan yang telah } \\
\text { ditentukan. }\end{array}$ & 5,59 & 4,53 & 7,62 & $-2,00$ & 1,06 \\
\hline & $\begin{array}{c}\text { Rel8 } \\
(8)\end{array}$ & $\begin{array}{l}\text { Kemampuan pustakawan dalam } \\
\text { menjawab pertanyaan yang saya } \\
\text { ajukan. }\end{array}$ & 5,91 & 4,69 & $\begin{array}{c}7,68 \\
\text { (tertinggi) }\end{array}$ & $-1,80$ & 1,22 \\
\hline
\end{tabular}




\begin{tabular}{|c|c|c|c|c|c|c|c|}
\hline \multicolumn{3}{|c|}{$\begin{array}{l}\text { Fasilitas \& Suasana Ruang Perpustakaan } \\
\text { (Library as Place - LP) }\end{array}$} & \multirow[b]{2}{*}{5,98} & \multirow[b]{2}{*}{$\begin{array}{c}4,83 \\
\text { (ter-tinggi) }\end{array}$} & \multirow[b]{2}{*}{7,52} & \multirow[b]{2}{*}{$-1,50$} & \multirow[b]{2}{*}{1,15} \\
\hline \multirow[t]{2}{*}{$\begin{array}{l}\text { Berwujud/ } \\
\text { ada bukti fisik } \\
\text { (Tangibles) }\end{array}$} & $\begin{array}{l}\operatorname{Tan} 9 \\
(9)\end{array}$ & $\begin{array}{l}\text { Ketersediaan buku-buku di } \\
\text { perpustakaan dalam membantu } \\
\text { saya menyelesaikan berbagai } \\
\text { tugas kuliah. }\end{array}$ & & & & & \\
\hline & $\begin{array}{c}\operatorname{Tan} 10 \\
(10)\end{array}$ & $\begin{array}{l}\text { Kondisi fisik gedung maupun } \\
\text { peralatan dan perlengkapan yang } \\
\text { cukup memadai dan berfungsi } \\
\text { baik. }\end{array}$ & 5,62 & 4,70 & 7,40 & $-1,78$ & 0,91 \\
\hline \multirow{2}{*}{$\begin{array}{l}\text { Ruang yang } \\
\text { bermanfaat } \\
\text { (Utilitarian } \\
\text { Space) }\end{array}$} & $\begin{array}{l}\text { Util1 } \\
\text { (11) }\end{array}$ & $\begin{array}{l}\text { Ketenangan ruangan } \\
\text { perpustakaan untuk belajar. }\end{array}$ & 5,84 & 4,65 & 7,42 & $-1,60$ & 1,19 \\
\hline & $\begin{array}{l}\text { Uti12 } \\
(12)\end{array}$ & $\begin{array}{l}\text { Adanya disain ruangan sebagai } \\
\text { tempat diskusi yang menarik } \\
\text { minat pemustaka. }\end{array}$ & 5,91 & 4,78 & $\begin{array}{l}7,12 \\
\text { (terendah) }\end{array}$ & $\begin{array}{c}-1,20 \\
\text { (terendah) }\end{array}$ & 1,14 \\
\hline \multirow[t]{2}{*}{$\begin{array}{l}\text { Berbagai makna } \\
(\text { Symbol) }\end{array}$} & $\begin{array}{c}\text { Sym13 } \\
(13)\end{array}$ & $\begin{array}{l}\text { Perpustakaan dapat } \\
\text { memunculkan berbagai inspirasi } \\
\text { untuk membaca dan belajar. }\end{array}$ & 5,88 & 4,54 & 7,38 & $\mathbf{1 , 5 0}$ & 1,33 \\
\hline & $\begin{array}{c}\text { Sym14 } \\
(14)\end{array}$ & $\begin{array}{l}\text { Perpustakaan terbuka untuk } \\
\text { civitas akademik dalam } \\
\text { belajar/berdiskusi bersama. }\end{array}$ & 6,02 & 4,73 & 7,42 & $-\overline{1,40}$ & 1,30 \\
\hline
\end{tabular}

\begin{tabular}{|c|c|c|c|c|c|c|c|}
\hline \multirow{2}{*}{$\begin{array}{l}\text { Tempat belajar } \\
\text { yang nyaman } \\
\text { (Refuge) }\end{array}$} & $\begin{array}{l}\text { Ref15 } \\
(15)\end{array}$ & $\begin{array}{l}\text { Ketersediaan ruangan di } \\
\text { perpustakaan yang nyaman } \\
\text { untuk belajar. }\end{array}$ & 5,96 & $\begin{array}{c}4,83 \\
\text { (tertinggi) }\end{array}$ & 7,52 & $-1,60$ & 1,14 \\
\hline & $\begin{array}{c}\text { Ref16 } \\
(16)\end{array}$ & $\begin{array}{l}\text { Kondisi perpustakaan yang selalu } \\
\text { bersih dan dijaga dengan baik } \\
\text { sehingga kondusif untuk belajar. }\end{array}$ & 5,69 & 4,77 & 7,52 & $-1,80$ & 0,93 \\
\hline \multicolumn{8}{|c|}{$\begin{array}{c}\text { Akses Informasi } \\
\text { (Information Access - IA) }\end{array}$} \\
\hline \multirow{2}{*}{$\begin{array}{l}\text { Isi/ruang } \\
\text { lingkup } \\
\text { (Content/ } \\
\text { Scope) }\end{array}$} & $\begin{array}{l}\text { Cont25 } \\
(25)\end{array}$ & $\begin{array}{l}\text { Ketersediaan koleksi (buku, } \\
\text { majalah, surat kabar, buku } \\
\text { referensi, maupun sumber } \\
\text { informasi lain) sesuai dengan } \\
\text { silabus dan kebutuhan saya. }\end{array}$ & 5,54 & 4,54 & 7,51 & $-2,00$ & 1,00 \\
\hline & $\begin{array}{l}\text { Cont26 } \\
(26)\end{array}$ & $\begin{array}{l}\text { Tersedianya bimbingan } \\
\text { pemustaka di perpustakaan pada } \\
\text { saat dibutuhkan. }\end{array}$ & $\begin{array}{c}\text { 6,10 } \\
\text { (tertinggi) }\end{array}$ & 4,42 & 7,35 & $\begin{array}{c}-1,20 \\
\text { (terendah) }\end{array}$ & $\begin{array}{c}1,68 \\
\text { (tertinggi) }\end{array}$ \\
\hline \multirow{2}{*}{$\begin{array}{l}\text { Kecepatan } \\
\text { waktu akses } \\
\text { (Timeliness) }\end{array}$} & $\begin{array}{l}\operatorname{Tim} 27 \\
\text { (27) }\end{array}$ & $\begin{array}{l}\text { Kelancaran dalam mengakses } \\
\text { berbagai informasi yang saya } \\
\text { butuhkan. }\end{array}$ & 5,46 & 4,41 & 7,60 & $-2,10$ & 1,05 \\
\hline & $\begin{array}{c}\operatorname{Tim} 28 \\
\text { (28) }\end{array}$ & $\begin{array}{l}\text { Kemudahan akses untuk } \\
\text { menemukan informasi yang } \\
\text { relevan dan akurat melalui alat } \\
\text { bantu katalog. }\end{array}$ & 5,49 & $\begin{array}{c}4,06 \\
\text { (teren-dah) }\end{array}$ & 7,59 & $-2,10$ & 1,43 \\
\hline
\end{tabular}

Sumber: Data primer diolah, 2011. 


\begin{tabular}{|c|c|c|c|c|c|c|c|}
\hline \multicolumn{8}{|c|}{ Petunjuk \& Sarana Akses (Personal Control - PC) } \\
\hline $\begin{array}{l}\text { Kemudahan } \\
\text { akses (Ease of } \\
\text { Navigation) }\end{array}$ & $\begin{array}{c}\text { Eas17 } \\
\text { (17) }\end{array}$ & $\begin{array}{l}\text { Kemudahan saya dalam } \\
\text { melakukan penelusuran } \\
\text { informasi di perpustakaan. }\end{array}$ & 5,73 & 4,65 & $\begin{array}{r}7,49 \\
\end{array}$ & $-1,80$ & 1,07 \\
\hline \multirow{2}{*}{$\begin{array}{l}\text { Kenyamanan } \\
\text { individu } \\
\text { pemustaka } \\
\text { (Convenience) }\end{array}$} & $\begin{array}{c}\text { Conv19 } \\
(19)\end{array}$ & $\begin{array}{l}\text { Kejelasan petunjuk atau panduan } \\
\text { penggunaan fasilitas layanan di } \\
\text { perpustakaan. }\end{array}$ & 5,63 & 4,56 & 7,51 & $-1,90$ & 1,07 \\
\hline & $\begin{array}{c}\text { Conv20 } \\
(20)\end{array}$ & $\begin{array}{l}\text { Kenyamanan waktu yang } \\
\text { dibutuhkan dalam mendapatkan } \\
\text { informasi di perpustakaan. }\end{array}$ & 5,77 & 4,64 & 7,58 & $-1,80$ & 1,12 \\
\hline \multirow[t]{2}{*}{$\begin{array}{l}\text { Peralatan yang } \\
\text { modern } \\
\text { (Modern } \\
\text { Equipment) }\end{array}$} & $\begin{array}{c}\text { Mod21 } \\
\text { (21) }\end{array}$ & $\begin{array}{l}\text { Ketersediaan fasilitas mesin foto } \\
\text { kopi di perpustakaan yang } \\
\text { membantu saya memperoleh } \\
\text { bahan perpustakaan yang saya } \\
\text { butuhkan. }\end{array}$ & 5,12 & 4,63 & 7,73 & $\begin{array}{c}-2,60 \\
\text { (tertinggi) }\end{array}$ & 0,49 \\
\hline & $\begin{array}{c}\operatorname{Mod} 22 \\
(22)\end{array}$ & $\begin{array}{l}\text { Adanya peralatan software } \\
\text { sebagai alat bantu penelusuran } \\
\text { koleksi buku maupun indeks } \\
\text { artikel jurnal/majalah. }\end{array}$ & 5,43 & 4,49 & 7,53 & $-2,10$ & 0,94 \\
\hline \multirow{2}{*}{$\begin{array}{l}\text { Kepercayaan } \\
\text { diri (Self } \\
\text { Reliance) }\end{array}$} & $\begin{array}{c}\text { Sel23 } \\
\text { (23) }\end{array}$ & $\begin{array}{l}\text { Saya dapat melakukan sendiri } \\
\text { dalam mencari informasi di } \\
\text { perpustakaan. }\end{array}$ & 5,68 & 4,52 & 7,47 & $-1,80$ & 1,16 \\
\hline & $\begin{array}{l}\text { Sel24 } \\
(24)\end{array}$ & $\begin{array}{l}\text { Kemampuan saya dalam } \\
\text { menggunakan sarana } \\
\text { perpustakaan dalam menelusur } \\
\text { informasi. }\end{array}$ & 5,38 & 4,68 & 7,42 & $-2,00$ & 0,70 \\
\hline
\end{tabular}

Lanjutan tabel halaman 12

Apabila dianalisis berdasarkan setiap butir pertanyaan berdasarkan nilai rata-rata persepsi (perceived), harapan minimum (minimum), dan harapan ideal (desired), maka lebih jelasnya dapat dilihat pada Gambar 3 dalam bentuk diagram radar.

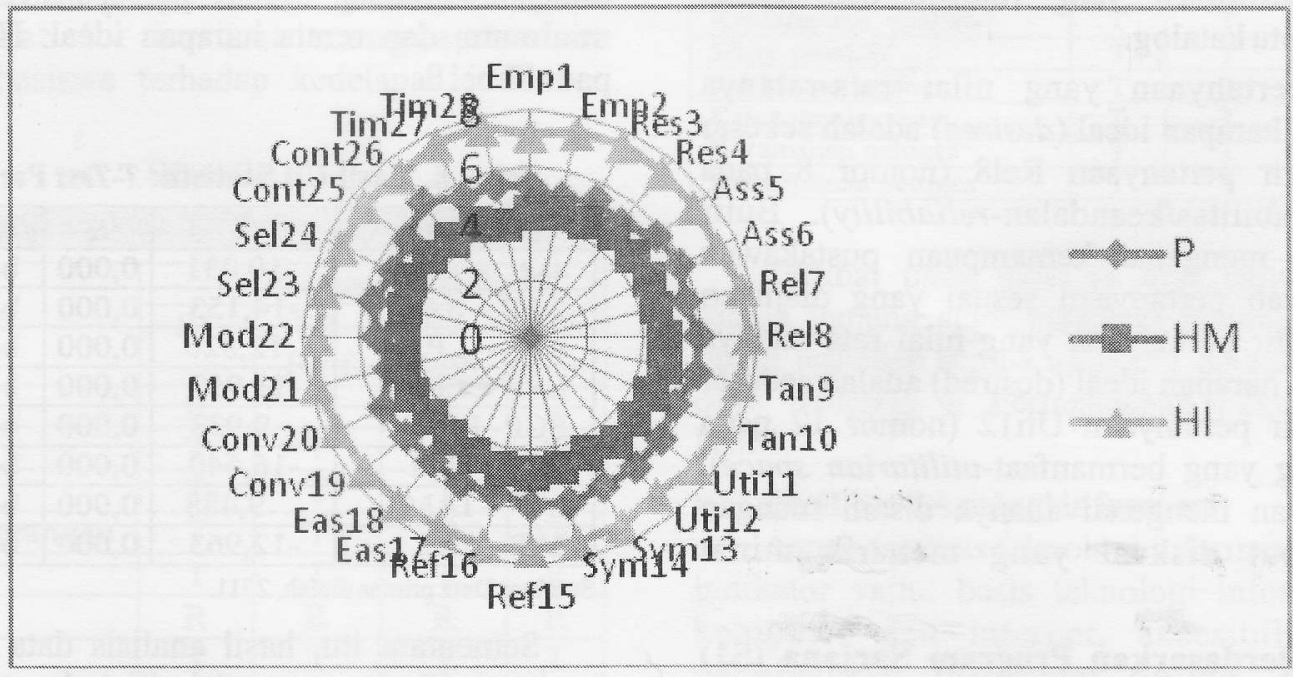

Gambar 3. Diagram Radar (Radarchart) Persepsi, Harapan Minimum, dan Harapan Ideal Sumber: Data primer diolah, 2011. 
Pada Gambar 3 nampak bahwa butir pertanyaan yang memiliki nilai rata-rata tertinggi untuk persepsi sebesar 6,10 adalah butir pertanyaan Cont26 (nomor 26 pada indikator isi/ruang lingkup-content/scope). Butir pertanyaannya mengenai tersedia bimbingan pemustaka pada saat dibutuhkan. Sementara nilai ratarata terendah pada persepsi sebesar 5,04 adalah pada butir pertanyaan Emp2 (nomor 2 pada indikator empati/kepedulian-empathy) mengenai pustakawan memberikan perhatian yang sungguh-sungguh kepada pemustaka.

Butir pertanyaan yang nilai rata-ratanya tertinggi untuk harapan minimum (minimum) sebesar 4,83 ada 2 (dua) yaitu:

1. Tan 9 (nomor 9 pada indikator berwujud/ada bukti fisik-tangibles), mengenai ketersediaan bukubuku di perpustakaan dalam membantu pemustaka menyelesaikan tugas-tugas kuliah.

2. Ref15 (nomor 15 pada indikator tempat belajar yang nyaman-refuge), mengenai ketersediaan ruangan yang nyaman untuk belajar.

Butir pertanyaan yang nilai rata-ratanya terendah untuk harapan minimum (minimum) adalah sebesar 4,06 pada butir pertanyaan Tim28 (nomor 28 pada indikator kecepatan waktu akses-timeliness). Butir pertanyaan mengenai kemudahan akses untuk menemukan informasi yang relevan dan akurat melalui alat bantu katalog.

Butir pertanyaan yang nilai rata-ratanya tertinggi untuk harapan ideal (desired) adalah sebesar 7,68 pada butir pertanyaan Rel8 (nomor 8 pada indikator reliabilitas/keandalan-reliability). Butir pertanyaannya mengenai kemampuan pustakawan dalam menjawab pertanyaan sesuai yang diajukan pemustaka. Butir pertanyaan yang nilai rata-ratanya terendah untuk harapan ideal (desired) adalah sebesar 7,12 pada butir pertanyaan Uti12 (nomor 12 pada indikator ruang yang bermanfaat-utilitarian space). Butir pertanyaan mengenai adanya disain ruangan sebagai tempat diskusi yang menarik minat pemustaka.

\section{Analisis Berdasarkan Program Sarjana (S1) dan Diploma Tiga (D3)}

Analisis berdasarkan program Sarjana (S1) dan Diploma Tiga (D3) akan menggambarkan kualitas layanan Perpustakaan FEB UNDIP berdasarkan sudut pandang 2 (dua) kelompok responden.Dilihat dari nilai Adequacy Gap (AG) program Sarjana (S1) lebih kecil sebesar 0,55. Sementara itu, dari nilai Superiority Gap (SG) program Sarjana (S1) nilai negatifnya lebih besar, yaitu-4,45. Dari hasil nilai AG dan SG tersebut, maka dapat disimpulkan bahwa ternyata mahasiswa Program Diploma Tiga (D3) lebih merasa "cukup puas" dalam merasakan kualitas layanan yang diberikan oleh Perpustakaan FEB UNDIP daripada mahasiswa Program Sarjana (S1). Temuan yang diperoleh dari analisis berdasarkan kelompok responden ditemukan bahwa mahasiswa program D3 lebih baik persepsinya dibanding mahasiswa program S1.

\section{Pengujian Hipotesis}

Untuk pengujian hipotesis menggunakan alat bantu SPSS dengan menggunakan teknik mean difference. Selanjutnya dengan T-test digunakan untuk menguji empat dimensi dalam kualitas layanan, yang meliputi: Kemampuan \& Sikap Pustakawan Dalam Melayani (Service Affect - SA), Fasilitas \& Suasana Ruang Perpustakaan (Library as Place - LP), Petunjuk \& Sarana Akses (Personal Control - PC), dan Akses Informasi (Information Access - IA). Uji mean difference dengan T-test tersebut dilihat dari rerata persepsinya, rerata harapan minimum, dan rerata harapan ideal.

Setelah dilakukan analisis data, maka hasil analisis dengan uji perbedaan rata-rata (mean difference) dengan T-test pada kedelapan hipotesis, adalah terdapat perbedaan dari masing-masing dimensi terhadap rerata persepsi, rerata harapan minimum, dan rerata harapan ideal. Hal ini seperti pada Tabel 8

Tabel 8. Hasil Uji Statistik T-Test Per-Dimensi

\begin{tabular}{|l|r|r|l|}
\hline \multicolumn{1}{|c|}{ Dimensi } & \multicolumn{1}{|c|}{ T } & $\alpha$ & Keterangan \\
\hline SAP - SAM & 10,031 & 0,000 & beda nyata \\
\hline SAP - SAI & $-14,153$ & 0,000 & beda nyata \\
\hline LPP - LPM & 12,826 & 0,000 & beda nyata \\
\hline LPP - LPI & $-11,952$ & 0,000 & beda nyata \\
\hline PCP- PCM & 9,933 & 0,000 & beda nyata \\
\hline PCP - PCI & $-16,540$ & 0,000 & beda nyata \\
\hline IAP - IAM & 9,488 & 0,000 & beda nyata \\
\hline LAP - IAI & $-12,963$ & 0,000 & beda nyata \\
\hline
\end{tabular}

Sumber: Data primer diolah, 2011.

Sementara itu, hasil analisis data dari masingmasing indikator yang telah dilakukan pada keempat dimensi LibQUAL ${ }^{+\mathrm{TM}}$ (28 indikator) semuanya juga terbukti dan berbeda nyata.

\section{E. Kesimpulan dan Saran}

\section{Kesimpulan}

Hasil uji hipotesisnya semua terbukti dan hasil rerata yang didapatkan berbeda nyata. Hasil analisis data menggunakan Adequacy Gap 
(AG) dan Superiority Gap (SG), dapat disimpulkan bahwa kualitas layanan Perpustakaan FEB UNDIP telah dapat memenuhi harapan minimum pemustaka.

Metode LibQUAL $^{+\mathrm{TM}}$ yang digunakan untuk mengukur kualitas layanan Perpustakaan FEB UNDIP menunjukkan bahwa berdasarkan analisis Adequacy Gap (AG), maka dimensi yang belum memenuhi harapan dan persepsi pemustaka adalah dimensi Information Access (IA) sebesar 5,160. Sementara itu, berdasarkan dari hasil analisis Superiority Gap (SG), maka dimensi Personal Control (PC) adalah dimensi yang belum memenuhi harapan dan persepsi pemustaka sebesar-15,889.

Jadi dapat disimpulkan bahwa dimensi layanan perpustakaan yang "belum memenuhi harapan dan persepsi pemustaka" di Perpustakaan FEB UNDIP dengan menggunakan metode LibQUAL $+{ }^{\mathrm{TM}}$ adalah dimensi Petunjuk \& Sarana Akses (Personal Control$P C)$ dan dimensi Akses Informasi (Information Access- $I A)$. Lebih jelasnya bahwa:

a. Dimensi Petunjuk \& Sarana Akses (Personal Control-PC) terletak pada belum tersedianya fasilitas mesin foto kopi di Perpustakaan FEB UNDIP.

b. Dimensi Akses Informasi (Information Access$I A)$ terletak pada:

- belum tersedianya koleksi (buku, majalah, surat kabar, buku referensi, maupun sumber informasi lain) yang sesuai dengan silabus dan kebutuhan pemustaka.

- ketidaklancaran dalam mengakses berbagai informasi yang dibutuhkan pemustaka.

- kesulitan akses dalam menemukan informasi yang relevan dan akurat melalui alat bantu katalog.

Analisis Adequacy Gap (AG) dari keempat dimensi, maka urutan dimensi dari yang "paling banyak belum berkontribusi memuaskan responden" adalah: 1). Dimensi Information Access (IA) sebesar 5,160 (paling jelek atau buruk, karena paling jauh dari harapan pemustaka); 2). Dimensi Service Affect (SA) sebesar 7,407; 3. Dimensi Personal Control (PC) sebesar 7,617; dan 4). Dimensi Library as Place (LP) sebesar 9,074 (paling baik, karena mendekati harapan pemustaka).

Sementara pada analisis Superiority Gap (SG), maka urutan dimensi dari yang "paling jauh dalam batas toleransi responden" adalah sebagai berikut: 1). Dimensi Personal Control (PC) dengan nilai sebesar - 15,889 (paling jelek atau buruk, karena paling jauh dari harapan pemustaka); 2). Dimensi Service Affect $(S A)$ dengan nilai sebesar - 15,605;3). Dimensi Library as Place (LP) dengan nilai sebesar 12,395; dan 4). Dimensi Information Access (IA) dengan nilai sebesar - 7,457 (paling baik, karena mendekati harapan pemustaka).

Selanjutnya layanan perpustakaan yang " belum memenuhi harapan dan persepsi pemustaka" pada masing-masing dimensi LibQUAL $+{ }^{\mathrm{TM}}$ berdasarkan analisis $\mathrm{AG}$ dan $\mathrm{SG}$, dapat penulis simpulkan sebagai berikut:

a. Dimensi Kemampuan \& Sikap Pustakawan Dalam Melayani (Service Affect - SA), yaitu pada: Pustakawan yang tidak selalu tanggap dalam memberikan bantuan pemustaka pada saat mencari informasi yang diperlukan; dan Pustakawan yang belum memberikan perhatian yang sungguh-sungguh kepada pemustaka.

b. Dimensi Fasilitas \& Suasana Ruang Perpustakaan (Library as Place - LP), yaitu pada: Kondisi fisik gedung maupun peralatan dan perlengkapan yang belum cukup memadai dan tidak berfungsi baik; dan Kondisi perpustakaan yang tidak selalu bersih dan tidak dijaga dengan baik sehingga tidak kondusif untuk belajar.

c. Dimensi Petunjuk \& Sarana Akses (Personal Control - PC), yaitu pada: Belum tersedianya fasilitas mesin foto kopi di Perpustakaan FEB UNDIP yang membantu pemustaka memperoleh bahan perpustakaan yang dibutuhkan.

d. Dimensi Akses Informasi (Information Access $L A)$, yaitu pada: Belum lengkapnya ketersediaan koleksi (buku, majalah, surat kabar, buku referensi, maupun sumber informasi lain) yang sesuai dengan silabus dan kebutuhan pemustaka; Ketidaklancaran dalam mengakses berbagai informasi yang dibutuhkan pemustaka; dan kesulitan akses untuk menemukan informasi yang relevan dan akurat melalui alat bantu katalog yang disediakan di Perpustakaan FEB UNDIP.

Temuan lainnya menunjukkan bahwa dari jumlah responden sebanyak 81 mahasiswa semuanya menunjukkan bahwa ternyata mereka setiap hari/sering sekali berkunjung ke Perpustakaan FEB UNDIP.

\section{Saran}


Berdasarkan hasil penelitian ini kualitas layanan Perpustakaan FEB UNDIP sudah memenuhi harapan minimum pemustaka dan pemustaka sudah merasa cukup puas, namun sebagai implikasinya tetap harus diperbaiki. Evaluasi kualitas layanan Perpustakaain FEB UNDIP dengan metode LibQUAL ${ }^{+T M}$ hendaknya terus dilakukan secara berkala, berkelanjutan, dan berkesinambungan. Alasannya karena dari hasil temuan penelitian ini ternyata kualitas layanan Perpustakaan FEB UNDIP masih berada di bawah harapan ideal pemustaka.

Apabila dilihat dari nilai AG dan SG yang paling buruk, maka dimensi yang masih jauh dari harapan dan perlu segera diperbaiki adalah pada:

a. Dimensi Akses Informasi (Information AccessIA). Dimensi Petunjuk \& Sarana Akses (Personal Control-PC).

Apalagi dengan pesatnya kemajuan Teknologi Informasi dan Komunikasi (TIK) saat ini yang seharusnya memberikan kesempatan untuk akses informasi secara terbuka tanpa memandang batas waktu, tempat/wilayah, maupun jarak.

b. Dimensi Petunjuk \& Sarana Akses (Personal Control-PC).

Perpustakaan FEB UNDIP hendaknya menyediakan berbagai fasilitas penting dan sarana akses untuk memberikan kemudahan kepada pemustaka dalam akses informasi yang dibutuhkan.

Perpustakaan FEB UNDIP perlu diatur dengan suatu sistem agar dapat memberikan layanan yang baik kepada pemustaka. Selain itu, agar kualitas layanan bisa mencapai atau bahkan melebihi harapan pemustaka, sehingga pemustaka menjadi sangat puas dengan layanan yang diberikan, maka saran penulis adalah "librarian must have big ear to users". Maksudnya bahwa pustakawan harus mendengar semua saran dari pemustaka.

Perkembangan TIK yang melahirkan peningkatan profesi pustakawan, maka pustakawan hendaknya mempunyai ketrampilan dasar (basic needs) dalam hal: library skill, computer skill, service skill, problem solving skill, maupun general qualities skill.

Kaitannya dengan metode LibQUAL ${ }^{+\mathrm{TM}}$ maka kunci kepuasan pemustaka terletak pada bagaimana pemustaka dan pihak Perpustakaan FEB UNDIP dapat membantu dengan sungguh-sungguh untuk memenuhi harapan minimum dan harapan ideal pemustaka.
Implikasi yang dapat disampaikan oleh penulis kepada pihak manajemen Perpustakaan FEB UNDIP dan para pemangku kebijakan di FEB UNDIP adalah agar segera melakukan perbaikan. Kaitannya dengan metode LibQUAL ${ }^{+T M}$, maka kunci kepuasan pemustaka sebenarnya terletak pada bagaimana pustakawan \& pihak Perpustakaan FEB UNDIP dapat membantu dengan sungguh-sungguh untuk memenuhi harapan minimum dan harapan ideal pemustakanya. Beberapa saran yang penulis sampaikan berdasarkan temuan dalam penelitian ini, antara lain:

a. Perlu peningkatan soft skill dan kompetensi pustakawan Perpustakaan FEB UNDIP dengan berbagai pelatihan maupun ketrampilan. Maksudnya adalah agar pustakawan Perpustakaan FEB UNDIP menjadi lebih tanggap dalam memberikan bantuan kepada pemustaka pada saat memerlukan informasi.

b. Perlu bagi pustakawan FEB UNDIP untuk lebih memberikan perhatian yang sungguh-sungguh kepada pemustaka.

c. Perlu penambahan waktu layanan berkaitan dengan kondisi pemustaka dalam mengakses berbagai informasi di perpustakaan. Baik perpanjangan jam buka layanan malam hari maupun pada hari Minggu.

d. Perlu penambahan ruangan maupun peralatan dan perlengkapan yang memadai dan berfungsi baik. Misalnya: ruang diskusi, ruang baca lesehan, ruang hotspot/wifi, toilet dan mushola di dalam perpustakaan, kantin perpustakaan (library cafe), mesin ATM, printer, dan lain sebagainya.

e. Perlu menjaga kondisi perpustakaan agar tampak selalu bersih dan baik dengan memberdayakan khusus untuk tambahan petugas kebersihan, sehingga tercipta suasana yang kondusif untuk belajar.

f. Perlunya penambahan fasilitas perpustakaan yaitu fasilitas mesin foto kopi yang membantu pemustaka dalam memperoleh bahan perpustakaan yang dibutuhkan.

g. Perlu perbaikan secara berkala pada sarana \& prasarana perpustakaan yang belum memadai dan kurang berfungsi baik. Misalnya: rak, meja baca, kursi, komputer.

h. Perlu penambahan koleksi (buku, majalah, jurnal, surat kabar, buku referensi, maupun sumber informasi lain) yang sesuai silabus dan kebutuhan pemustaka. 
i. Perlu penambahan fasilitas anjungan penelusuran yang berupa Online Public Access Catalogue (OPAC) di setiap ruang Perpustakaan FEB UNDIP agar pemustaka menjadi lebih lancar dan mudah dalam mengakses berbagai informasi yang dibutuhkan.

j. Perlu memberikan kegiatan pendidikan pemustaka (user education), baik berupa orientasi perpustakaan (library orientation), instruksi perpustakaan (library instruction), maupun instruksi bibliografi (bibliographic instruction) bagi pemustaka. Tujuannya untuk memudahkan mengakses informasi dan menemukan kembali informasi yang dibutuhkan. Harapannya pemustaka dapat lebih familier dalam menelusur informasi melalui alat bantu katalog yang telah disediakan di Perpustakaan FEB UNDIP.

Rekomendasi mengenai metode LibQUAL ${ }^{+\mathrm{TM}}$, maka peneliti merekomendasikan kepada para pustakawan dan pengelola perpustakaan di Indonesia untuk menerapkan metode $\mathrm{LibQUAL}^{+\mathrm{TM}}$ dalam mengevaluasi kualitas layanan perpustakaan. Hal ini disebabkan bahwa berdasarkan pengamatan peneliti, metode yang sering digunakan hanya SERVQUAL saja, padahal ada metode terbaru yang lebih tepat/cocok yaitu dengan $\mathrm{LibQUAL}^{+\mathrm{TM}}$.

Dari hasil penelitian ini, peneliti membuktikan dan menegaskan bahwa metode LibQUAL ${ }^{\mathrm{TM}}$ adalah metode yang tepat/cocok untuk mengukur kualitas layanan di perpustakaan. Namun demikian, agar dimensi dan indikator dalam metode LibQUAL ${ }^{+T M}$ berkembang, maka perlu dikembangkan lagi oleh para peneliti lain khususnya di Indonesia sesuai situasi dan kondisi perkembangan perpustakaan di Indonesia.

Implikasi (implications) ke depannya (research limitations) penulis merekomendasikan agar LibQUAL $^{+T M}$ dapat difokuskan pada berbagai jenis perpustakaan dan dianalisis kualitatif dari sudut pandang budaya yang berbeda.

\section{DAFTAR PUSTAKA}

Boykin, Joseph F. 2002. "LibQUAL" ${ }^{+T M}$ as a Confirming Resource." Performance Measurement and Metrics, Vol.3, p. 74-77.

Budd, John M. 2005. The Changing Academic Library: Operations, Cultures, Environments. America:ACRL Publications in Librarianship.

Cook, Colleen and Fred M. Heath. 2001.'Users' Perception of Library Service Quality: A LibQUAL ${ }^{+\mathrm{TM}}$ Qualitative Study". Library Trends, 9(4), Spring, p. 548-584.

Cook, Colleen, et.al. 2001. "LibQUAL ${ }^{+\mathrm{TM}}$ : Service Quality Assessment in Research Libraries." International Federation of Library Association and Institution (IFLA) Journal. 27 (4), p. 265-268.

Fatmawati, Endang. 2011. The Art of Library: Ikatan Esai Bergizi Tentang Seni Mengelola Perpustakaan. Edisi Revisi. Semarang: BP UNDIP.

.2011. "Kajian Teoritis Mengenai Metode LibQUAL ${ }^{+T M}$ Untuk Mengevaluasi Kualitas Layanan Perpustakaan." LIBRARIA Jurnal Ilmu Perpustakaan dan Informasi FPPTI Jateng, Volume 1 Nomor 1, Juni 2011, hal 45-80. ISSN. 2088-7310.

Grandey, Alicia A. et.al. 2006. "Service with A Smile and Encounter Satisfaction: Emotional Contagion and Appraisal Mechanisms". Academy of Management Journal, Vol.49(6).

Hitchingham, et.al. 2002. Extracting Meaningful Measures of User Satisfaction from LibQUAL ${ }^{+\mathrm{TM}}$ for The Libraries at Virginia Tech". Performance Measurement and Metrics, Vol. 3, p. 48-58.

Kemp, Jan H. 2001. "Using the LibQUAL ${ }^{+{ }^{+M}}$ Survey to Assess User Perception of Collections and Service Quality". Collection Management, Vol. 26, p. 1-14.

Ladhari, Riadh and Morales, Miguel. 2008. "Perceived Service Quality, Perceived Value and Recommendation: A Study Among Canadian Public Library Users". Library Management, Vol. 29, No. 4/5, p. 352-366. 
Lancaster, Frederick Wilfrid. 1993. The Measurement and Evaluation of Library Services. Washington: Information Resource Press.

LibQUAL $^{+\mathrm{TM}}$. Tersedia dalam http://www.libqual.org. Diakses tanggal 25 Oktober 2010.

Ping, Chia Yip and Edzan, N.N. 2008. "Evaluating User's Level of Satisfaction wit The Chinese Studies Collection Held at An Academic Library." Malaysian Journal of Library \& Information Science, 13(2), p. 103-119.
Powell, Ronald R. and Connaway, Lynn Silipigni. 2004. Basic Research Methods for Librarians. Fourth Edition. USA: Libraries Unlimited.

Simpson, Ian Stuart. 1988. Basic Statistics for Librarians. $3^{\text {rd }}$ ed. London: Library Association \& Chicago: American Library Association.

Wolfe, Lisa A. 2004. Library Public Relations, Promotions, and Communications. Second Edition. New York: Neal-Schuman Publishers.

Woodward, Jeannette A. 2009. Creating The Customer Driven Academic Library. Am 